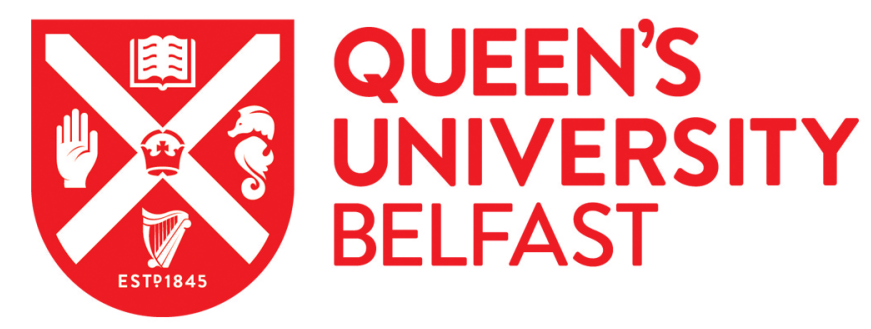

\title{
Seen and Not Heard: Students' uses and experiences of silence in school relationships at a secondary school
}

Hanna, A. (2021). Seen and Not Heard: Students' uses and experiences of silence in school relationships at a secondary school. Childhood. https://doi.org/10.1177/09075682211055605

\section{Published in:}

Childhood

Document Version:

Publisher's PDF, also known as Version of record

Queen's University Belfast - Research Portal:

Link to publication record in Queen's University Belfast Research Portal

\section{Publisher rights}

Copyright 2021 the authors.

This is an open access article published under a Creative Commons Attribution License (https://creativecommons.org/licenses/by/4.0/), which permits unrestricted use, distribution and reproduction in any medium, provided the author and source are cited.

\section{General rights}

Copyright for the publications made accessible via the Queen's University Belfast Research Portal is retained by the author(s) and / or other copyright owners and it is a condition of accessing these publications that users recognise and abide by the legal requirements associated with these rights.

Take down policy

The Research Portal is Queen's institutional repository that provides access to Queen's research output. Every effort has been made to ensure that content in the Research Portal does not infringe any person's rights, or applicable UK laws. If you discover content in the Research Portal that you believe breaches copyright or violates any law, please contact openaccess@qub.ac.uk. 


\title{
Seen and not heard: Students' uses and experiences of silence in school relationships at a secondary school
}

2021 , Vol 0(0) $1-15$

(c) The Author(s) 202

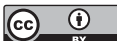

Article reuse guidelines: sagepub.com/journals-permissions DOI: I0.1 I77/090756822।I055605 journals.sagepub.com/home/chd @SAGE

\author{
Amy Hanna \\ Queen's University Belfast, Belfast, UK
}

\begin{abstract}
Silence is traditionally understood as a power deficit; yet, it creates spaces in which power works unobtrusively. In this article, I report the findings of a qualitative study examining silence in school relationships. Based on nine conceptual discussions and 33 interviews with teachers and students in a secondary school in the UK, I assert that uses of silence in relationships between students and teachers revolve around two conceptions of power: a stronghold of respect and a refuge for dignity.
\end{abstract}

\section{Keywords}

Silence, power, respect, dignity, relationships

\section{Introduction}

Traditional understandings of 'silence' largely revolve around 'complete lack of noise or sound' (Oxford Learner's Dictionary, 2021), yet silence can be 'full and resonant' (CookSather, 2006: 369); a re-examination of the terms and values that underlie silence is necessary. The necessity of such an examination is highlighted by Cook-Sather (2006: 369) who posits that, instead of a state of powerlessness, 'silence can be powerful-a withholding of assent, a political act'. Baurain (2011) warns that silence cannot be seen as a matter of power or lack of power, voice or lack of voice, because, as Glenn (2004: 18) observes, 'silence can deploy power; it can defer to power'. This paradoxical relationship between sound and silence becomes obscured when an equation is made between voice 
and autonomy, and the inverse, silence and oppression (Malhotra and Rowe, 2013). Instead, silence may be central to understanding the elusive aspects of power, and this is particularly the case when examining relationships that have a marked power differential such as those between students and their teachers. Of course, it is necessary to recognise that some uses of silence are overwhelmingly positive, including the creation of respectful spaces where students and teachers actively listen. Nevertheless, whilst acknowledging the considerable literature on the centrality of positive relationships to behaviour management in schools (see, for example, McCluskey, 2014; McCluskey et al., 2013; Munn et al., 2009; Sullivan et al., 2016; Slee, 1995), this paper builds on previous reporting of data on silence in teaching and learning practices (Hanna, 2021) to illuminate how silence may be powerful and political, how it manifests itself in resistance and defiance, and what this means for school relationships.

Before reporting these findings, I first propose a hybrid conceptualisation of silence with which I hope to capture its inherently complex nature as a form and a practice, underpinned by various values and motivations: silence is simultaneously a state of being and an equivocal space into which we project our motivations, according to our needs and desires, with 'desire' taking Mazzei (2011) definition of a silent voice produced by longing for normative power and privilege. I assert that these needs and desires centre around power and authority and are primarily those of saving face, whether this be as a stronghold or a refuge. In this paper, I will argue, firstly, that uses of silence, as they pertain to behaviour in schools, centre around conceptions of authority which govern who can speak and when; such conceptions demand a critical analysis of silence and power from which to examine the themes of dignity and respect which emerged from the data. Secondly, I will argue that silence as a medium of power and control manifests itself in two clear, but related, practices of silence: as a stronghold where the discourse is dominated by expectations of respect and as a refuge where the legitimacy of power is negotiated with reference to individual authority to have students' voices heard and taken seriously as a matter of dignity. Both these practices, I will argue, go to the centre of how students are represented, their relative positions of power in the school structure, and the ensuing silences which serve to control them.

\section{Existing taxonomies of silence}

Issues of voice are embedded in structures and relations of power (Cook-Sather, 2006; Taylor and Robinson, 2009). Fielding (2004) asserts that 'who is speaking, who is spoken of, and who listens is a result, as well as an act, of political struggle'. How student voice is defined, what forms it takes, who listens and how it is interpreted depends, in part, on the relationship that exists between teacher and student and the context in which this relationship exists (Cook-Sather, 2006). A consideration of silence as a dimension of student voice, therefore, is apt because it addresses this paucity of attention to the context which influences both what students say, and what remains silent. The term 'voice' does not acknowledge complex individual subjectivities, or the role of, and relationship between, power and domination; some scholars suggest this amounts to essentialism (see, for example, Alcoff, 1995; Orner, 1992; Weiler, 1991; Ellsworth, 1992; Taylor and 
Robinson, 2009; Cook-Sather, 2006; Fielding, 2004 for a discussion). To address such criticism, poststructuralists argue that the frameworks of interpretation must be accounted for (see, for example, Spyrou, 2011, 2016; Mazzei, 2009; Mazzei and Jackson, 2012); there is little work, however, on what alternatives might look like (cf. Lewis, 2010). I suggest that drawing together these concepts of power and voice is the oft overlooked matter of silence and, implicitly, the significance of power and authority in practices of silence. To understand the role of power, we must examine the interstitial spaces of silence, in which meaning is ambiguous, judgement is withheld, and opinion is deferred because this is the way in which power works unobtrusively (Achino-Loeb, 2006). To do this, it is first necessary to examine existing taxonomies of silence and to understand what they tell us about power and authority.

Spyrou (2016) warns that although taxonomies of silence can be heuristically useful, no taxonomy of silence can be exhaustive because research is likely to reveal varieties of silence with differing power dynamics which demand different kinds of listening. Indeed, it might be more useful to consider that silence is what silence conveys: the purposes which underpin its uses; hence, my definition of silence in this article as both a stronghold and a refuge. Nevertheless, existing taxonomies of silence provide a useful basis upon which to explore where silence and social interactions converge because they attend to power and authority. Whilst there are a number of taxonomies which frame how it might be understood (for example, Saville-Troike, 1985; Bruneau, 1973; Jaworski, 1993), one of the earliest taxonomies of silence by Bruneau (1973) is useful for the purposes of this article because it attends to the realities of power, social norms and expectations that are inherent in an examination of silence in school relationships. Bruneau (1973) asserts a framework of silence which distinguishes between three categories: psycholinguistic, interactional and sociocultural. I consider, in this article, Bruneau's consideration of interactive and sociocultural silences because they attend to power and authority.

Interactive silences are interruptions in dialogue or discussion and concern the interpersonal relationships between individuals, as well as the exchange of information or knowledge (Bruneau, 1973). These silences are characterised by participant recognition of the manner in which they are expected to participate in dialogue; interactive silences are therefore closely bound to the character of the message sharing process and to the context in which this takes place. This is significant because in identifying such a category of silence, Bruneau's taxonomy helps to address one of the core criticisms of student voice: that it does not take into account individual subjectivities or context. Furthermore, such socio-contextual silences are indicative of role and status, but are also situational in managing or controlling tension, and include tactical and attitudinal silences such as those of non-participation and respect (Bruneau, 1973). Bruneau (1973) further suggests that the character of power is discernible in interactive silences, particularly in authoritysubordinate relationships, such as those between teacher and student.

Power has incontrovertible connections with status, and the form and process of attributing status appears to gain visibility as a result of interactive silences. Those who infringe the norm are often treated in turn with interactive silences where authoritysubordinate relationships become more conspicuous, and the identity of communicators, including their social status, affects the appropriate patterns of silence and speech 
(Saville-Troike, 1985). The final form of silence considered by Bruneau (1973) is sociocultural silence which Bruneau suggests may define our cultural patterns of communication better than what is spoken, pointing out that conceptions of authority are often conceptions of what can be spoken about, and who can speak. Bruneau (1973) contends that these sociocultural silences are used to show respect for position which demonstrates recognition of authority. Discipline codes operate in this sense, where authority positions are protected by rules and obligatory norms aimed at maintaining order.

To understand the relevance of the concepts of respect and authority to both practices of silence and relationships in schools, it is helpful to examine the relationship between respect, authority and dignity. Whilst this is a relationship that has been the subject of moral philosophy for centuries, it is easily understood through Darwall (2006) who argues that the dignity of persons includes the authority to speak and be heard. Indeed, McCrudden (2008) argues that the concept of dignity is an intrinsic worth on account of being a human which should be respected by others. Darwall (2006) reminds us that respect for dignity is also grounds for resistance to authority. Silence in this context, may be seen when someone refuses to give space for others to be heard or refuses to listen. Darwall (2006) asserts that this is disrespect: a violation of dignity. The only empirical research to examine the workings of authority in practices of silence at school was undertaken by Gilmore (1985) who highlighted the transmission and reproduction of power through silence. Gilmore (1985) ethnographic study took place over 3 years in a mostly low income, black urban community and elementary school in the United States. For teachers, he found that silent displays demonstrated disapproval of students' behaviour and sought to restore order and control. Student silences could be a communicative strategy aimed at other students as well as the teacher and were used primarily in Gilmore's observation as a way of displaying emotion.

Largely, student silences were to facilitate the discourse of the teacher, a phenomenon discussed by Hanna (2021), which could indicate both submission and defiance where 'stylized sulking' challenged authority and saved face in front of peers, often turning loss of face back on the teacher (Gilmore, 1985: 148). Whilst Bruneau's taxonomy illustrates how teachers in positions of authority use silence as a display of strength and power, students in Gilmore's study similarly used it as a refuge or defence and a means of saving face. Interestingly, this silent display has the same effect and meaning as teacher displays designed to attract attention and signal that behaviour is felt to be inappropriate or unfair. Such displays are invariably linked to power where students' uses of silence indicates their refusal to align themselves with authority.

\section{Methodology}

Whilst Gilmore (1985) ethnographic study is the only study which explores silence in relation to power and school relationships, his data were observational and did not include consultation with students or teachers. This study adopted a children's rights-based methodology (Lundy and McEvoy, 2012) to examine how students and teachers understood, used, and experienced silence in relationships with others at school. This study took place with students in year 11, and their teachers, at a secondary school in the UK in 
recognition of their evolving capacities as they were approaching their 15 th birthday. The school was predominantly monocultural with a white British demographic, located in a low socioeconomic ward.

In total, 42 young people and 27 teachers participated in the study. Participants were recruited using purposive selection and each gave their informed, written consent. All reported names in this article are pseudonyms to uphold confidentiality and anonymity. Where names are not indicated, quotes are from conceptual discussions where names were not recorded in transcription. Quotes in italics are reported speech from participants. For student participants, parental 'opt-out' consent was employed in recognition of participants' age and increasing maturity; no opt-out forms were received. The methods employed were twofold: conceptual group discussions and semi-structured interviews. A total of 42 young people participated in nine conceptual discussions which established deliberative, democratic dialogue driven by young people's own ideas and thinking (Cassidy, 2017) about power and silence. These were followed by interviews of up to three students or teachers respectively. Overall, 35 students engaged in 15 interview sessions, and 20 teachers engaged in 18 interview sessions.

Young people participated in conceptual discussions which were based on the Community of Philosophical Inquiry (CoPI) (Cassidy et al., 2019), founded on the pedagogical approach established by Philosophy for Children (Lipman, 2003). The form used in this study is termed conceptual discussions for two reasons: firstly, I am not a trained philosopher and therefore do not have the expertise to position myself as a practitioner of CoPI and secondly, my use of conceptual discussion was not to pursue philosophical inquiry per se, but to build young people's capacity to explore the abstract content around power and silence. Three classes of young people from year 11 participated in conceptual discussions and each class addressed the same questions: i) What is knowledge? ii) What is power? and iii) What is silence? These conceptual discussion groups were seated in a circle, and I presented them with a stimulus at the beginning of each session; two stimuli were video clips exploring knowledge and power respectively from the Harry Potter series and one stimulus was an orchestral performance of John Cage's 4'33 composition in which silence plays an integral part. My role was to facilitate young people's responses; once the question for each session was shared, young people developed their own positions in response to the question and considered arguments for and against their respective positions.

Conceptual discussions did not seek a conclusion or consensus because to do so might lead participants to consider the question dealt with and completed, and suggest that there is no space for disagreement (Cassidy, 2017) which would conflict with the study's constructivist approach to knowledge. Subsequent semi-structured interviews offered young people the chance to continue conversations that occurred in conceptual discussions, and to voice thoughts and ideas that occurred to them after the conceptual discussions. Teachers participated in semi-structured interviews because this was crucial to understanding the role of silence in student teacher relationships. All data were audio recorded and transcribed, and subsequently coded inductively using NVivo. Data were analysed using thematic analysis (Braun and Clarke, 2006, 2012). As the implications of silence for teaching and learning are reported elsewhere (see Hanna, 2021), this paper 
reports the findings of the study on silence in the context of school relationships, beginning with the motives and intentions which underpinned practices of silence, before reporting both students' and teachers' individual uses of silence. The twin themes of power and authority, and respect and dignity, which transcend these findings, are explored in the discussion which follows.

\section{Rethinking relationships: Findings on silence}

\section{Motives and intentions of silence in school relationships}

Uses of silence for discipline, control and punishment. Students and teachers overwhelmingly explained their uses and experiences of silence in their school relationships as a form of control, using it to engender silence of students and thus to control behaviour, and as not listening or permitting students to speak. However, whether students were forced to be silent seemed to differ amongst students. Olivia and Natalie were ambivalent as to whether this constituted force, suggesting that teachers standing at the front waiting for silence, was a nice way of... forcing it on you (Natalie). This way of engendering silence may be more appropriately understood as coercion: a more persuasive, and silent, use of power.

In a conceptual discussion, one group of students discussed how they were not able to respond to teachers in disciplinary scenarios because this was seen as being smart. Not being allowed to justify yourself was something, the students suggested, that made them less comfortable in the class. This silencing had specific repercussions for the learning environment, as Ben later suggested being able to have a conversation or like a sort of argument; the teacher is able to respond and you're able to respond to that. I think that's just, like... communication. That's sort of knowledge. You are able to respond. This was echoed in an interview with other students who stated that teachers expect you not to say anything back to them cause like they're teachers but like it's not really that fair... (Anna)

Teachers were much more likely to describe silences in terms of expectation and requirements, and teachers' positioning in the classroom in this respect was often implicitly authoritarian. Caroline, a teacher, emphasised that I don 't talk if anybody's talking. I just don't think, I mean if you teach the class they listen. Right. Full stop. Another teacher, Brian, explained his expectations in terms of similarly authoritarian understandings of control:

Brian: It's for everyone's good at the end of the day, you know, otherwise no one's going to achieve nothing cause they're all going to, just, play along that game and even the very best in the class you'll have absolutely no control over because they just talk over the top of you and show you no respect or, or whatever and just talk over you, you know.

Silence here is understood as a way of controlling students who are seen to lack selfcontrol. This control centres around the understanding of silence as based upon values, and desires, which produce 'order', reinforce the status quo of teacher power, and in doing so, employ silence as a stronghold for hegemonic power. The underlying presumption is 
that the control mechanism is to be found in the silence of students. This of course has distinct implications at an individual level, and it is to these silences that we now turn.

\section{Individual silences in school relationships: Use and application}

Using silence to ignore and avoid. There was a striking association between practices of silence that were used in processes of exclusion to make a person feel uncomfortable, like a spare piece, and to make them feel like they don't want to... intrude (Sarah). This particular aspect of silence was discussed repeatedly by participants in relation to the 'silent treatment' in ignoring their existence:

Hannah: Well everyone wants to be seen and heard. So not being seen and heard by someone that you love or like care for; it's awful.

Another group of students, however, described silence as a buffer by which to take time until we're both like ready and calm to like actually discuss it (Olivia). This included selfexclusion, when students had reached their limit; if they were uncomfortable, they would exclude themselves using silence so that you don't get talked to (Hannah and Izzie). Students spoke at length about avoiding peers they did not like, avoiding teacher questioning which risked embarrassment and avoiding certain conversations with others because maybe they don't know what to say (Ben). This avoidance was a form of silence that was also recognised by students because sometimes people stay silent like and don't address things because they don't want to deal with it. In this way, silence served to avoid confrontation, but also to maintain the status quo. There are thus power repercussions to this form of silence, and students discussed how teachers ignore students in their management of the classroom. This was affirmed by a teacher in interview who referred to 'tactical ignoring' of students:

Joanne: ...there are so many children that are ignored. You know. Now, it can be tactical ignoring. I don't agree with that, I don't like that, but em, there are children who probably have a lot of silence happens to them at school, or even at home. And there's a message going to them that actually what you're saying actually isn't worthwhile so I'm not going to listen to you.

Such practices of silence demand critical reflection when considered in relation to young people's dignity; 'tactical ignoring' is in direct conflict with Darwall (2006) definition of dignity as the authority to speak and be heard. This raises the question of responses to these silences. Students often described their responses in emotional terms and in a way that captured how such forms and practices of silence created the 'feeling' of the classroom environment and school culture as a whole.

Using silence for emotion. One of the striking findings from the study was the association and practices of silence regarding emotion. Uses of silence on the part of teachers in propagating silence to control was often equated with strong emotions like anger: if 
they're mad they'll just stare at you and be silent. There was also an acknowledgement by students of the emotional ramifications of silence: some suggested punishment and others suggested intimidation. The emotional aspects of silence were also applied to embarrassment: shaming of students using silence to draw attention to them as a medium of control demonstrated the authority which underpinned such practices. Students often described silence in terms of disappointment on the part of adults and explained that this can be worse sometimes (Deborah) because it makes you feel bad (Emily). One student described these silences using a popular song lyric sometimes the quiet is violent (Connie) which aptly captured the ambiguity and tension which many students experienced in uses of silence. Silence was also used to avoid imposing these negative emotions on others:

Lydia: It's like Benthamism. Like you don't want to come across as weak.

$[\ldots]$

Lydia: The strong survive and the weak deserve to die.

Researcher: Like survival of the fittest?

Lydia: Yeah I think so. It's in Of Mice and Men so...

Researcher: Wow! So if you stay silent, you won't be seen as what?

Lydia: Weak. Like you don't want to tell everybody your problems.

Researcher: And what are you using silence for there? That's not to protect other people from your pain, what are you using silence for there?

Lydia: To strengthen yourself almost.

Melanie: To create a fake image of yourself.

As this excerpt demonstrates, however, the silences around and within emotional capital are more complex than might first appear: silence is seen as a position of strength, or as a protective barrier, in the face of emotional pain or perplexity, and this served to present a 'strong' or fake front to others. This was explored by Chris, a teacher, as an expression of emotion which can manifest in silent defiance:

Chris: ...they're just rejecting to do it because they are hurting inside, over something, some particular thing that has happened and they're taking it out on the lesson and on that particular task. And I think that that is perhaps within them a coping mechanism because they don't necessarily want to deal with the thing that they are upset about; it's too painful, or too hurtful.

Here, when it comes to silence and emotions, silence could be used to present self from a position of strength - a stronghold - when really it is being used as a refuge - a shield.

Using silence for resistance. Several students identified how silence could be used as resistance. One student responded I don't know (Connie) to teacher questions when she 
felt she was being picked on, using her subordinate status to subvert authority. Sometimes, students would not respond when they were expected to: ...basically just don't do the work and if a teacher tells them to do it they just sit there and... look away (Greg). Lydia suggested that this was a bit like rebellion, which could break through another's power by refusing to give them an answer and, therefore, defying them. One key consequence of school practices of expecting silence and imposing it on students at the teachers' discretion may be that students use it to resist teacher authority. Not only is silence used to control and sometimes to punish, but dialogue is also controlled. This is problematic when the 'expectation' is to speak, even if students do not wish to do so; their silence becomes, perhaps, a medium of being heard by which their dignity is retained.

Teachers also identified this use of silence as resistance. What two teachers termed silent defiance (Eric and Helen) may be interpreted as an imposition of students' own autonomy in the form of a buffer between teacher speaking authority and student silent conformity: a matter of control. One teacher explained that this silence was harder to deal with, perhaps because control over the dialogue had moved to the student:

Kate: ...if you've got someone who is silently defiant and they don't give you anything back, how can you build that relationship with that pupil if they just don't want to have a relationship with you? I feel like you're hitting a brick wall on some occasions.

Perhaps the most striking silence here is that this practice of repairing breakdown in relationship seemed to be based on an assumption that the student felt they had a relationship with the teacher. For some students, there was no relationship to be repaired. One young man described this as a black hole, and their 'brick wall' was the view and experience of teachers as strangers (Luke). Interestingly, when probed about this view of teachers, Luke was himself perplexed about the feeling, saying I know I've known them for four years but, I still like-don't really like- I don't even know. This may, of course, suggest that students feel the need to resist, but are not always aware of why they have this feeling, and cannot, therefore, make this form of silence intelligible. Such is the power of silence that some students struggled to make sense of their own uses of silence, but on probing, could understand that they were engaging in forms of resistance.

Applying silence to respect. Whilst the central relevance of silence to respect in pedagogy has been reported elsewhere (Hanna, 2021), respect was also a crucial form of silence when considering relationships in school. The concept of respect was a foundation of the Discipline Policy which was built upon respect, for one another and for authority. Students were required by the Discipline Policy to speak to their teachers, learning support assistants and other school staff and pupils with respect. Frequent references to respect were noted throughout the school, with one wall display representing 'respect' in the form of a mnemonic:

$\mathrm{R}$ : recognise that everyone is different;

E: empathy is to listen and connect; 
S: self-monitor: think first;

P: personal space: give a little space;

E: earn trust through your actions;

C: cheer on others and their success;

T: treat everyone as an equal.

This wall display suggests that respect is understood in terms of diversity, listening, self-censorship, personal autonomy, trust and equality; all terms which recurred throughout the study in reference to silence, and, particularly, relationships. The findings, however, suggested something of a contradiction between silence, censorship and respect. Silence was likened to a perception of respect as censorship - an individual silence which restricts students' expression. One student framed this practice in terms of learning respect: think before you speak, you know like, thinking like, what the consequences are going to be if you say this (Adam). In this particular situation, Adam was referring to suppression of a curse word, suggesting that this censorship bred frustration on the part of young people who could not express their emotions or viewpoints, and reflecting how use of silence for emotion discussed above was applied to the role of respect in school relationships. This student's suppression of response to teachers was reflected in what another student described as holding in how you feel (Poppy) because they would probably just get worse offfor it, if you do tell them (Jack). When applied to respect, these silences took the form of suppressing expression of feelings and emotions, and of views and opinions. As discussed in reference to tactical ignoring above, this contradicts Darwall (2006) definition of dignity as the authority to speak and be heard because young people have been refused a space to be heard, to express themselves or to be listened to; what Darwall defines as 'disrespect'.

Considering that conceptions of authority govern who can speak and when, the underpinnings of respect may therefore be understood as outworkings of authority, and a covert reminder to young people about their place in school relationships: subordinate. The unspoken role of authority was especially clear when considering teacher respect towards students:

Connie: They say like respect your elders and then they'll go and shout at you for no reason.

Say you go up and put a piece of paper in the bin, and they'll shout at you.

Here, the implicit suggestion is that teachers should not have to be respected by young people simply because of their position; rather, they should show that they have a desire to get on (Emily) with them. Teachers' responses also support this finding: one particular teacher spoke at length about students showing respect to teachers. When asked what he meant by 'respect', he responded not listening to you (Brian). Indeed, this was the case for other teachers: in my mind that is disrespectful if they will not listen to me and if they don't respect you, they won't stay quiet (Kate). Yet, the Heads of Year 11, with whom the study took place, clearly stated that if young people did not feel respected, they would not 'buy 
into' teacher authority or power. This feeling of the absence of respect was explained as being spoken down to, or treated like a child (Helen), in contrast to treating young people with respect by giving them a bit of responsibility and reciprocity: if you're wanting them to show you that then you have to show that towards them as well (Helen).

This was framed as seeing them as a human being other than just a pupil (Helen); what we understand in terms of dignity. Indeed, in one group discussion about 'what is power'? one young person aptly captured this concept of human dignity, asserting that everyone's human at the end of the day, and should be treated accordingly.

\section{Discussion}

The research question focussing on uses and experiences of silence in school relationships becomes more nuanced when we differentiate between the power disparity inherent in school relationships to control and punish students, and the authority that infuses how such relationships are perceived by students as legitimate, or otherwise. I argue in this discussion that the findings illuminate practices of silence that demonstrate the void around discussions of respect as a concept that is in grave need of clarification: to the extent that it may rely on concepts of power and authority for its meaning, which have not been sufficiently examined and to the extent that behaviour management policies which hinge on the notion of respect need to clarify the nuances around the concept in order to form a new paradigm for the management of relationships in school. The findings illuminate the workings of both power and authority in uses of silence for school discipline and highlight how these silences reflect whose voices are heard. Silence is, therefore, a medium of power and authority which, I argue, manifests itself in two clear, but related, practices. The first is a stronghold of 'respect' for those with greater power in school relationships; this manifests as control and punishment. The second is a refuge for saving face and preserving dignity for those who wish to reinstate their individual worth and value in the face of others with greater power; this manifests in resistance and avoidance.

The interplay between sound and silence is central to the exercise of power and authority in school. Whilst Attali (2017) explains that 'noise' indicates the limits of territory and how individuals are heard within that space, I argue that silence can render such boundaries ambiguous. There is an inherent dualism here in that power is exercised in the production of sound, but authority is negotiated in silent acts of listening and hearing; subjects thus use sound and voice, or hearing and listening to produce spaces in which to lay claims to territory, and to delineate spaces in which to exercise power as a stronghold or negotiate authority in refuge. The concept of authority is crucial to practices of silence because, as the definition in this article highlights, silence is an equivocal space into which we project our motivations according to our needs and desires. These needs and desires centre around power and authority - often, as Mazzei (2011) argues, the desire to reproduce existing power relations of privilege. Both these practices of silence, as a refuge and a stronghold, reflect understandings of and assertions of dignity and respect, both of which are central to relationships in school. I argue that this autonomous preservation of dignity manifests itself in uses of silence as a refuge, where a student, for example, uses silence to negotiate their perceptions of legitimacy around power practiced 
by teachers and their own subordinate status. When used as a stronghold, however, authority and status are already present and thus the uses and experiences of silence by teachers often manifest themselves as indicators, or expectations, of respect.

Respect is the fitting response to dignity because in respecting someone we view them as having the authority to make claims, have them heard and taken seriously. This research suggests that recognition of authority may centre on expectations of students to maintain silence as an indication of respect for their 'elders' rather than intrinsic worth on account of being human (see Darwall, 2006; McCrudden, 2008). In respectful silence detailed in the findings, young people learnt to withhold their voice because of the desire to avoid punishment or embarrassment in front of their peers; when saying something posed a threat to a student's dignity, silence became a refuge. Notably, in this study, students' exercise of power and performance of silence was simultaneously attributed meanings by teachers which served to conceal students' uses of silence as a refuge for dignity. For example, some teachers described students as not wanting to learn or as being incapable of learning. One teacher termed this 'tactical ignoring' which, for her, indicated to a young person that what they had to say was not worthwhile or valued: an erosion of students' dignity.

The many equations of silence with respect raises questions about culture and cultural understandings of silence. Bruneau (1973) attributes great power to sociocultural silence to manipulate interactional and psycholinguistic silences. The findings of this study demonstrate that the relationships between teachers and students are imbued with the equation of silence equals respect. Control of the social order of the school was bound together not only by articulate statements of value, for example, the conduct code, but shared zones of silence which removed the urge to speak about certain subjects, such as how certain students perceived their relationships with their teachers. This was summed up by a student who referred to his teachers as 'strangers', and by others in the same class who explained that '[teachers] don't know us'. Interestingly, this suspicion of authority figures may represent a central form of silence as a form of resistance and distrust which was a powerful means of neutralising this power at certain moments of tension. Unable to voice their views and have them taken seriously, students' defiant silence was an attempt to seize control of the situation in order to save face, and thereby preserve their dignity.

Respect, as the findings suggest, was understood as conformity, as opposed to a concept anchored in practices of reciprocity and dignity. Students' frustration at being ignored or patronised underpinned their conceptions of respect. Their concerns about how they were often not permitted to respond in disciplinary scenarios, owing to teachers' expectations that they remain silent in deference to authority, raises the question of how 'respect' may be understood differently by young people and teachers. This may highlight the tension that emerges around the concept and its relationship with power and authority: respect can be wielded as a vehicle of power, but also utilised as a shield or defence in negotiating authority. These tensions manifest in practices of silence which, in this research, illuminate how the concept of respect is far from a commonly understood concept in secondary school, but a contentious notion that has the capacity to be divisive and to reinforce polarisation between students and their teachers. 


\section{Conclusion}

Silence, in this research, is repositioned as a reflection of the social construction of the school around power and an ambiguous space in which we navigate and negotiate authority and individual dignity. In this study, teachers' uses of silence to engender silence originated from a stronghold of power and accompanying expectation of respect, and students often employed silence as a means of evasion and resistance to both negotiate teacher authority and to preserve their dignity. Silence in school relationships, therefore, highlights conceptualisations of respect which dominate the discourse around silence from a position of strength, but conceptualisations of dignity are less common, where the legitimacy of this power is negotiated with reference to individual authority. By examining how uses and practices of silence reflect the conceptualisations of power and respect in school, we can address the lacuna in our understandings of respect to establish school relationships that do not rely on hegemonic assumptions about power and authority, but fundamental dignity of the person.

\section{Declaration of Conflicting Interests}

The author(s) declared no potential conflicts of interest with respect to the research, authorship, and/ or publication of this article.

\section{Funding}

The author(s) disclosed receipt of the following financial support for the research, authorship, and/or publication of this article: This research was funded by the Northern Ireland Executive's Department of Employment and Learning (now Department for the Economy).

\section{ORCID iD}

Amy Hanna (D) https://orcid.org/0000-0002-1101-5211

\section{References}

Achino-Loeb M (ed), (2006) Silence: The Currency of Power. Oxford: Berghahn.

Alcoff L (1995) The problem of speaking for others. In: Bell LA and Blumfeld D (eds), Overcoming Racism and Sexism. Lanham, MD: Rowman and Littlefield, pp. 229-254.

Attali J (2017) 'Noise and Politics'. In: Cox C and Warner D (Eds) Audio Culture: Readings in Modern Music, New York: Bloomsbury Academic, 7-11.

Baurain B (2011) Teaching, listening and generative silence. Journal of Curriculum Theorizing 27(3): 89-101.

Braun V and Clarke V (2006) Using thematic analysis in psychology. Qualitative Research in Psychology 3(2): 77-101.

Braun V and Clarke V (2012) Thematic analysis. In: Cooper H (ed), APA Handbook of Research Methods in Psychology. Washington, DC: American Psychological Association, Vol. 2.

Bruneau TJ (1973) Communicative silences: forms and functions. The Journal of Communication 23: $17-46$. 
Cassidy C (2017) Philosophy with children: A rights-based approach to deliberative participation. International Journal of Children's Rights 25: 320-334.

Cassidy C, Conrad S-J and de Figueriroa-Rigo MJ (2019) Research with children: a philosophical, rights-based approach. International Journal of Research and Method in Education 43(1): 38-52. DOI: 10.1080/1743727X.2018.1563063.

Cook-Sather A (2006) Sound, presence and power: 'student voice' in educational research and reform. Curriculum Inquiry 36(4): 359-390.

Darwall S (2006) The Second-Person Standpoint: Morality, Respect, and Accountability. Cambridge, USA: Harvard University Press.

Ellsworth E (1992) 'Why doesn't this feel empowering? working through the repressive myths of critical pedagogy'. In: Luke C and Gore J (eds), Feminisms and Critical Pedagogy. New York: Routledge, pp. 90-119.

Fielding M (2004) Transformative approaches to student voice: theoretical underpinnings, recalcitrant realities. British Educational Research Journal 30: 295-311.

Gilmore P (1985) Silence and sulking: emotional displays in the classroom. In: Tannen, D. and Saville-Troike M. (eds), Perspectives on Silence. Norwood, NJ: Ablex, pp. 139-162.

Glenn C (2004) Unspoken: A Rhetoric of Silence. Carbondale, IL: Southern Illinois University Press.

Hanna A (2021) SIlence at school: Uses and experiences of silence in pedagogy at a secondary school. British Educational Research Journal 47(5): 1158-1176.

Jaworski A (1993) The Power of Silence: Social and Pragmatic Perspectives. London: Sage.

Lewis A (2010) Silence in the context of child voice'. Children and Society 24(1): 14-23.

Lipman M (2003) Thinking in Education. 2nd ed.. Cambridge, Massachussets: Cambridge University Press.

Lundy L and McEvoy L (2012) Children's rights and research processes: Assisting children to (in) formed views. Childhood 19(1): 129-144.

Malhotra S and Rowe AC (2013) Silence, Feminism, Power: Reflections at the Edges of Sound. Basingstoke: Palgrave Macmillan.

Mazzei L (2011) Desiring silence: gender, race and pedagogy in education. British Educational Research Journal 37(4): 657-669.

Mazzei L (2009) An impossibly full voice. In: Jackson AY and Mazzei LA (eds), Voice in Qualitative Inquiry: Challenging Conventional, Interpretive, and Critical Conceptions in Qualitative Research. London: Routledge, pp. 97-113

Mazzei L and Jackson A (2012) Complicating voice in a refusal to 'let participations speak for themselves'. Qualitative Inquiry 18(9): 745-751.

McCluskey G, Brown J, Munn P, et al (2013) 'Take more time to actually listen': reflections on participation and negotiation in school. British Educational Research Journal 39(2): 287-301.

McCluskey G (2014) 'Youth is present only when its presence is a problem': voices of young people on discipline in school. Children and Society 28(2): 93-103.

McCrudden C (2008) Human dignity and the judicial interpretation of human rights. European Journal of International Law 19(4): 655-724.

Munn P, Lloyd G, Cullen G, et al (2009) Behaviour in Scottish Schools 2009-Final Report. Edinburgh: Scottish Government. 
Orner M (1992) 'Interupting the calls for student voice in "liberatory" education: A feminist poststructuralist perspective'. In: Luke $\mathrm{C}$ and Gore $\mathrm{J}$ (eds), Feminisms and Critical Pedagogy. New York: Routledge, pp. 74-89.

Oxford Learner's Dictionary (2021) Oxford: Oxford University Press, Accessed 01 November 2021. Available at: https://www.oxfordlearnersdictionaries.com/definition/english/silence_1? $\mathrm{q}=$ silence.

Saville-Troike M (1985) The place of silence in an integrated theory of communication. In: Tannen D and Saville-Troike M (eds), Perspectives on Silence. Norwood, NJ: Ablex, pp. 3-18.

Slee R (1995) Changing Theories and Practices of Discipline. London: Falmer Press.

Spyrou S (2011) The limits of children's voices: from authenticity to critical, reflexive representation. Childhood 18(2): 151-165.

Spyrou S (2016) Researching children's silences: Exploring the fullness of voice in childhood research. Childhood 23(1): 7-21.

Sullivan A, Johnson B and Lucas B (eds), (2016) Challenging Dominant View on Student Behaviour at School: Answering Back. Berlin, Germany: Springer.

Taylor C and Robinson C (2009) Student voice: Theorizing power and participation. Pedagogy, Culture and Society 17(2): 161-175.

Weiler K (1991) Freire and a feminist pedagogy of difference. Harvard Educational Review 61(4): 449-474. 